\title{
OS RESQUícIOS DE PROVA TARIFADA NO PROCESSO CIVIL BRASILEIRO E SUA INFLUÊNCIA NO LIVRE CONVENCIMENTO DO MAGISTRADO
}

\section{Marcio Vieira'}

Resumo: Pretende analisar os resquícios de prova tarifada no processo civil brasileiro e sua influência no livre convencimento do magistrado. Faz um retrospecto acerca da figura do magistrado, as decisões proferidas e os sistemas de convencimento. Traz à baila apontamentos sobre teoria geral da prova e a forma de sua valoração. Elenca a forma pela qual a prova tarifada se manifesta no processo civil brasileiro e, então, define a postura do magistrado diante destes elementos probatórios em contraposição ao princípio do livre convencimento motivado.

Palavras-chave: Prova tarifada. Valoração da prova. Convencimento do magistrado.

\section{INTRODUÇÃO}

A tarefa de pacificação social exercida pelo magistrado não pode prescindir da análise da prova colhida nos autos. Esta apreciação dos fatos deve, então, estar pautada em critérios lógicos e capazes de conduzir a prestação jurisdicional à satisfação

1 Aluno da Escola Superior da Magistratura do Estado de Santa Catarina (ESMESC). Servidor do Tribunal de Justiça do Estado de Santa Catarina - TJSC. E-mail: vieira@tjsc.jus.br 
daqueles que elegeram o Estado como o ente pacificador dos conflitos sociais, evitando-se arbitrariedades e extrema discricionariedade por parte dos agentes estatais designados para o exercício da nobre função da judicatura.

Através de uma análise a respeito da evolução dos sistemas de convencimento do magistrado, o escopo do presente ensaio consiste em analisar a influência dos resquícios de prova tarifada, também denominada de prova legal, no ordenamento processual civil brasileiro e sua influência na formação da convicção do magistrado. Examina-se, então, a interferência de uma forma de valoração da prova em desuso diante do princípio do livre convencimento motivado.

Propõe-se, assim, em um primeiro momento, uma exposição sobre o aparecimento do fenômeno da jurisdição, da figura do juiz e suas manifestações processais, bem como sobre os sistemas de convencimento utilizados nos referidos atos. Em seguida, fazemse os necessários apontamentos sobre teoria geral da prova e a forma de sua valoração. Por fim, demonstra-se o modo pelo qual a prova tarifada aparece no ordenamento jurídico para, então, buscar a postura do magistrado diante de tais circunstâncias.

\section{A FUNÇÃO JURISDICIONAL E OS SISTEMAS DE CONVENCIMENTO}

Uma análise sobre o fenômeno da prova tarifada e os resquícios deixados no ordenamento jurídico brasileiro, bem como sua influência na formação do convencimento do magistrado, necessita, antes de qualquer outro exame, de uma contextualização sobre o aparecimento da jurisdição e do juiz e suas decisões, para, depois, conhecer o modus operandi dos mais conhecidos sistemas de formação do convencimento.

\subsection{A jurisdição, o Magistrado e as Manifesta- ções Judiciais}

O homem, na concepção de Aristóteles (2001, p. 219), é um ser político e, nesta condição, por não alcançar a plenitude 
da vida de uma forma isolada, está sujeito a viver em sociedade. Ocorre que diante desta obrigatoriedade inerente, nem sempre há uma harmonização entre interesses, razão pela qual se pode afirmar que desde os primórdios existe a necessidade de resolverem-se os conflitos, o que se traduz na afirmação de que "a função de julgar é tão antiga como a própria sociedade" (GUIMARÃES, 1958, p. 19).

Pode, portanto, desde o momento em que o homem passou a viver em sociedade, haver comumente a pretensão resistida de indivíduos em relação a determinados interesses de outrem, existindo a necessidade de serem ditadas as soluções dos conflitos. No entanto, em fases primitivas da organização social, inexistiam autoridades que garantissem o cumprimento do direito e quem pretendesse algo e fosse por outrem compelido, teria que alcançar a satisfação de sua pretensão por si mesmo, ou seja, pela autotutela.

O instituto da autotutela, entretanto, não garantia a plena justiça, mas tão somente a vitória daquele que possuísse atributos físicos e intelectuais capazes de despontar uma maior vantagem sobre outros indivíduos com o mesmo interesse, concepção esta que começa a ser modificada a partir do momento em que o Estado se afirma perante os interesses dos particulares, fase em que ele começa a ditar a solução dos conflitos e que inicia o nascimento do fenômeno intitulado jurisdição (GRINOVER, p. 13, 2007).

Cândido Rangel Dinamarco (2002, p. 115) define jurisdição como "a atividade pública e exclusiva com a qual o Estado substitui a atividade das pessoas interessadas e propicia a pacificação de pessoas ou grupos em conflito, mediante a atuação da vontade do direito em casos concretos". Assim, dentro de determinados limites, é concebido ao Estado o poder para aplicar o direito e, por consequência, solucionar os conflitos de interesses resolvidos anteriormente de uma forma precária pela autotutela.

Uma das principais características da jurisdição é sua inércia, ou seja, ela somente é exercida quando há provocação 
para que o Poder Judiciário julgue uma lide ${ }^{2}$, determinado a aplicação da lei ao caso concreto que lhe é apresentado. Este conflito de interesse, dada a qualidade do fenômeno jurisdição, deve ser solvido por um agente estatal, o qual possui a prerrogativa de ditar, de acordo com o ordenamento jurídico e sua convicção, a solução do conflito a ele designado.

Nas palavras de Valmir Bigal (2006, s.n):

A progressiva complexificação social, além do aumento populacional e territorial obrigava a delegação de certas atribuições a pessoas de confiança do chefe ou do príncipe, que cada vez mais se encontravam impossibilitados de atender pessoalmente a todas as demandas sociais. Permanecia a autoridade nele, mas o seu exercício tinha de ser dividido entre várias pessoas. Tal fato é um imperativo natural da especialização de funções e da divisão do trabalho.

Esta função é, então, desenvolvida pelo magistrado, que no Brasil, de acordo com a Constituição Federal ${ }^{3}$, ressalvadas as hipóteses de condução de advogados e membros do Ministério Público aos tribunais, o ingresso na carreira, cujo cargo inicial é o de juiz substituto, dá por concurso púbico de provas e títulos, com participação da Ordem dos Advogados do Brasil em todas as suas fases, exigido-se, ainda, do bacharel em direito três anos de atividade jurídica.

A atividade do juiz, em essência, manifesta-se pela prolação de uma sentença. Trata-se do climax do funcionamento da atividade jurisdicional. Porém, é corrediço que existe uma série de complexas operações no decorrer do processo que se alcance este fim. Dentre os extremos da marcha processual, que se inicia

2 Aqui se usa a definição de lide contida na exposição de motivos do Código de Processo Civil que, redigida por Alfredo Buzaid, remete ao conceito dado por processualista italiano, ao afirmar que "lide é, consoante a lição de CARNELUTTI, o conflito de interesses qualificado pela pretensão de um dos litigantes e pela resistência do outro. [...] A lide é, portanto, o objeto principal do processo e nela se exprimem as aspirações em conflito de ambos os litigantes".

3 Art. 93. [...] I - ingresso na carreira, cujo cargo inicial será o de juiz substituto, mediante concurso público de provas e títulos, com a participação da Ordem dos Advogados do Brasil em todas as fases, exigindo-se do bacharel em direito, no mínimo, três anos de atividade jurídica e obedecendo-se, nas nomeações, à ordem de classificação; 
com a propositura da ação e se finda com a decisão transitada em julgado, tem-se uma série de decisões que conduzem o magistrado à formação de seu convencimento.

De acordo com o escólio de Humberto Theodoro Júnior (2005, p. 255), "no comando do processo, o juiz está dotado de duas espécies de poderes: o de dar solução à lide, e o de conduzir o feito segundo o procedimento legal, resolvendo todos os incidentes que surgirem até o momento adequado à prestação jurisdicional”. Neste contexto, diante destas atribuições que lhe são impostas, o magistrado, com o intuito de formar sua convicção de acordo com os fatos e o direito, manifesta-se no decorrer da instrução através dos variados atos.

Genericamente, todo e qualquer pronunciamento que resolve uma controvérsia no decorrer do processo, de acordo com a lição de José Frederico Marques (1958, p. 41), é denominado "decisão". Esta amplitude da denominação pode ser decomposta de acordo com a carga ou efeito que a decisão proporciona ao sistema. É assim que o Código de Processo Civil, subdividindo os atos processuais, em consonância com o art. 162, proclama que "os atos do juiz consistirão em sentença, decisões interlocutórias e despachos".

O dispositivo do Códice em comento, além da classificação dos atos decisórios, também os conceitua. Evitando, então, maiores digressões a respeito do tema, classifica-se sentença como "o ato do juiz que implica alguma das situações previstas nos arts. $267^{4}$ e 2695" (§ 1\%), decisão interlocutória como "o

4 Art. 267. Extingue-se o processo, sem resolução de mérito: I - quando o juiz indeferir a petição inicial; II - quando ficar parado durante mais de 1 (um) ano por negligência das partes; III - quando, por não promover os atos e diligências que lhe competir, o autor abandonar a causa por mais de 30 (trinta) dias; IV - quando se verificar a ausência de pressupostos de constituição e de desenvolvimento válido e regular do processo; $\mathrm{V}$ - quando o juiz acolher a alegação de perempção, litispendência ou de coisa julgada; VI - quando não concorrer qualquer das condições da ação, como a possibilidade jurídica, a legitimidade das partes; VII - pela convenção de arbitragem; VIII - quando o autor desistir da ação; IX - quando a ação for considerada intransmissível por disposição legal; $X$ - quando ocorrer confusão entre autor e réu; XI - nos demais casos prescritos neste Código.

5 Art. 269. Haverá resolução de mérito: I - quando o juiz acolher ou rejeitar o pedido do autor; II - quando o réu reconhecer a procedência do pedido; III - quando as partes transigirem; IV - quando o juiz pronunciar a decadência ou a prescrição; $\mathrm{V}$ - quando o autor renunciar ao direito sobre que se funda a ação. 
ato pelo qual o juiz, no curso do processo, resolve questão incidente" $(\$ 2$ ) e, por fim, "são despachos todos os demais atos do juiz praticados no processo, de ofício ou a requerimento da parte, a cujo respeito a lei não estabelece outra forma" (\$ 3o).

Qualquer das decisões proferidas pelo magistrado, a teor do art. 93, IX ${ }^{6}$, da Constituição Federal, necessita ser fundamentada. É necessário frisar, entretanto, que há distinção entre "ausência de fundamentação" e "fundamentação concisa", conforme proclamado pelo Supremo Tribunal Federal, ao verberar: "A Constituição não exige que a decisão seja extensamente fundamentada. $\mathrm{O}$ que se exige é que o juiz ou Tribunal dê as razões de seu convencimento." (STF, AgR em AI 162089/ DF, Segunda Turma, rel. Min. Carlos Velloso, j. em 12.12.1995, DJU de 15.03.1996, p. 7.209).

Conquanto o ordenamento processual civil brasileiro mencione a existência de três atos decisórios prolatados pelo juiz, é na sentença - ou acórdão - que haverá uma cognição exauriente. Significa dizer, apesar da importância dos demais atos, que é na referida manifestação em que haverá a exteriorização efetiva do convencimento do magistrado, razão pela qual, no presente ensaio, será dada maior ênfase em relação a ela.

\subsection{Os Sistemas de Convicção}

A atividade cognitiva do juiz é pautada na investigação pela veracidade dos fatos, ou, nas palavras da doutrina de direito processual moderno, na busca pela verdade real (THEODORO JÚNIOR, 2005, p. 458) em contraposição ao mito da verdade formal (aquela unicamente contida nos autos). Entretanto, o magistrado não pode agir de uma forma arbitrária ao manipular a prova, ou seja, precisa ser orientado por uma sistemática de convencimento.

6 Art. 93. [...]IX - todos os julgamentos dos órgãos do Poder Judiciário serão públicos, e fundamentadas todas as decisões, sob pena de nulidade, podendo a lei limitar a presença, em determinados atos, às próprias partes e a seus advogados, ou somente a estes, em casos nos quais a preservação do direito à intimidade do interessado no sigilo não prejudique o interesse público à informação. 
A doutrina costuma afirmar que existem três grandes sistemas no que diz respeito aos critérios de formação do convencimento do magistrado, quais sejam: (i) o sistema da prova legal (tarifada); (ii) o sistema da livre convicção; e (iii) o sistema da persuasão racional. No entanto, antes de adentrar nos meandros de cada uma das sistemáticas, necessário consignar que tudo é fruto de evolução histórica. Assim, nos dizeres de Cândido Rangel Dinamarco (2001, p. 75):

Em tempos remotos, essas regras gerais de valoração da prova tiveram muito peso no processo civil, sendo fruto da superstição dos povos e, em alguma medida, da experiência do legislador. Foram de fundo supersticioso ou místico as ordálias ou juízos de Deus, vigorantes especialmente entre os antigos germânicos. Contava-se com a resposta divina, realizavam-se provas de destreza ou de força (duelos, prova per pugnam) e praticava-se o juramento, na crença, sincera ou não, de que esses fossem caminhos legítimos e confiáveis para a descoberta da verdade. A prova do fogo, a leitura do vôo dos pássaros ou o exame das vísceras de animais eram expedientes que revelariam os desígnios da divindade em favor de uma ou de outra parte do litígio. Segundo jocosamente se relata, a mulher acusada de bruxaria pelos Tribunais da Inquisição seria lançada a um poço com uma pesada pedra atada ao pescoço. Se se salvasse, isso seria prova de suas relações com o Demônio e ela iria para a fogueira. Se fosse ao fundo e morresse por afogamento, é porque seria inocente.

Em tempos menos remotos, a confiança em sua própria cultura e experiência, em associação com a crença na legitimidade das generalizações em tema de valoração da prova, levou o legislador, a editar normas valorativas de fundo racional (DINAMARCO, 2001, p. 75). Assim, a avaliação da prova deixou de ser realizada por eventos quaisquer e passou a ser procedida pelo próprio julgador, havendo um maior relevo científico, caracterizado pela existência de hierarquia dos meios probatórios. 
Preponderam, então, no sistema da prova legal, regras de valoração definidas pela lei em caráter geral e abstrato, e não pelo juiz, em cada caso específico. O legislador, antecipandose, estabelece juízo valorativo ao impor normas que graduam, exaltam, limitam ou excluem a eficácia das variadas fontes de prova, mediante verdadeiras tabelas de valores a serem observadas pelos juízes em geral. Elas constituem vínculos normativos à formação do convencimento pessoal do juiz, caracterizando-se por reduzir ou mesmo chegar próximo a aniquilar o espaço da valoração a ser feita por este em casos concretos (DINAMARCO, 2001, p. 74-75).

Na lição de Moacyr Amaral dos Santos (1986, p. 12):

No sistema da prova legal, a instrução probatória se destinava a produzir a certeza legal. $\mathrm{O}$ juiz não passava de um mero computador, preso ao formalismo e ao valor tarifado das provas, impedido de observar positivamente os fatos e constrangido a dizer a verdade conforme ordenava a lei que o fosse.

Do rigor estabelecido pela hierarquia legal do valor da prova, o processo conduz à uma verdade formal, que, em grande parte dos casos, não guarda nenhum vínculo com a realidade externa aos autos (THEODORO JÚNIOR, 2005, p. 459). Não é crível, então, que se exija uma postura negativa do julgador na apreciação da prova, dado que é ele quem observa e capta os diversos meandros ocorridos no decorrer da relação processual.

Assim, em contraposição à prova legal, surgiu o sistema da livre convicção, também conhecido por convencimento moral ou íntimo, caracterizado pela soberania conferida ao julgador em relação à apreciação das provas e ao questionamento da verdade. Não há qualquer limitação legal na formação de seu convencimento, dispensando-se, inclusive, a motivação das decisões. É dizer, nas palavras de Moacyr Amaral dos Santos (1986, p. 13):

[...] a verdade jurídica é a formada na consciência do juiz, que não é, para isso, vinculado a qualquer 
regra legal, quer no tocante à espécie de prova quer no tocante a sua avaliação. A convicção decorre não das provas, ou melhor, não só das provas colhidas, mas também do conhecimento pessoal, das suas impressões pessoais, e à vista destas lhe é lícito repelir qualquer ou todas as demais provas.

Dadas as características do instituto em comento, ao magistrado é dada a discricionariedade de decidir conforme sua convicção, que pode até mesmo ser formada com base em uma ciência privada, causando, em não poucas vezes, situações arbitrárias ao julgar com elementos estranhos à lide. Estes "poderes" atribuídos ao agente estatal tornam-se tão ilimitados a ponto de se "considerar o depoimento de uma testemunha, como capaz de suplantar o valor de uma escritura pública, ou admitilo como bastante para provar determinada obrigação, independentemente do valor econômico desta” (BARBI, 1991, p. 533).

Dada, então, a demasiada margem de discricionariedade concedida ao magistrado, que "vai ao extremo de permitir o convencimento extra-autos e contrário à prova das partes" (THEODORO JÚNIOR, 2005, p. 459), este instituto é permeado por críticas, razão pela qual encontra-se em desuso, observando, contudo, sua aplicabilidade, em relação ao direito penal, no procedimento de crimes afetos ao Tribunal do Júri.

Assim, tem-se como fruto da mais atualizada compreensão sobre a atividade jurisdicional, um novo sistema da persuasão racional, consagrado pelos códigos napoleônicos. Enquanto no livre convencimento o magistrado pode julgar sem necessariamente se atentar à prova produzida nos autos, neste sistema, a prolação da decisão deve ser fruto de uma operação lógica armada com base nos elementos de convicção expostos no processo (THEODORO JÚNIOR, 2005, p. 459).

Por meio deste critério de avaliação da prova e julgamento, há um livre convencimento por parte do magistrado, baseado na racionalidade, afastando-se, portanto, a ciência privada e impulsos extremamente pessoais do magistrado. Assim, 
um julgamento condizente com tais parâmetros exigirá uma produção intelectual calcada em todos os elementos e circunstâncias da prova coligida nos autos, sempre se atentando em relação a sua credibilidade.

Nas palavras Dinamarco (2001, p. 78):

O convencimento do juiz precisa ser motivado, porque sem o dever de motivar as decisões de nada valeriam as exigências de nacionalidade e atenção ao que consta dos autos. Aos leitores de suas decisões (partes, órgãos judiciários superiores, opinião pública) o juiz é devedor da explicação dos porquês de suas conclusões, inclusive quanto aos fatos. Ele tem o dever de desenvolver, na motivação das decisões, o iter de raciocínio que, à luz dos autos, o leva a concluir que tal fato aconteceu ou não, que tal situação existe ou deixa de existir, que os fatos se deram de determinado modo e não de outro, que dado bem, serviço ou dano tem tal valor e não mais nem menos etc.

Frisa-se, ademais, que a liberdade conferida ao magistrado na apreciação da prova não é mero arbítrio, mas critérios de atuação ajustado aos deveres profissionais. Há alvedrio no sentido de que o juiz examina as provas livremente, mas esta apreciação não pode se afastar dos fatos estabelecidos, das provas colhidas, das regras científicas, das regras jurídicas, das regras da lógica, e das regras de experiência (SANTOS, 1986, p. 14).

Assim, afastada a rigidez da prova legal e sem a arbitrariedade do sistema da livre convicção, o sistema da persuasão racional, tendo em consideração que a decisão final deve estar logicamente vinculada à apreciação do que restou demonstrado nos autos, é o que mais conduz a uma solução justa para o conflito trazido ao judiciário e, como se observará adiante, é o utilizado no ordenamento jurídico brasileiro, embora exista a presença dos refalados resquícios de prova tarifada. 


\section{DAS PROVAS E SUA VALORAÇÃO}

Como anteriormente afirmado, a atividade de conhecimento exercida pelo magistrado não pode prescindir da análise probatória contida nos autos, dado que a prova, além de um procedimento, é também um instrumento necessário para o desenvolvimento do raciocínio judicial, evitando decisões judiciais arbitrárias e discricionárias. Assim, atento ao escopo deste ensaio, é imprescindível o exame de conceitos operacionais básicos acerca da teoria geral da prova e a forma de sua valoração.

\subsection{Apontamentos Sobre Teoria Geral da Prova}

Os pretensos direitos subjetivos que figuram em uma lide são originários de situações concretas, fazendo-se necessário, para a obtenção de decisões coerentes e justas, que os fatos submetidos ao crivo Poder Judiciário sejam reconstituídos da maneira mais exata possível. Assim, a prova em sentido jurídico, na concepção de Carnelutti (2001, p. 72), consiste em demonstrar a verdade formal dos fatos discutidos, mediante procedimentos determinados, ou seja, através dos meios legítimos.

De acordo com o escólio de Leonardo Greco (2004, p. 397), "é no campo das provas que o processo pode aproximar-se da realidade da vida, contribuindo para que a justiça consiga dar razão a quem tem direito e, mesmo quando não o fizer, para que a sociedade possa nela confiar, por ter feito o máximo possivel para realizar esse ideal".

Conquanto a palavra "prova" possa reunir uma série de significados, no âmbito do processo civil, ela pode significar a atividade realizada pelos sujeitos do processo com a finalidade de demonstrar a existência dos fatos formadores do direito, bem como o instrumento pelo qual é feita essa verificação (SILVA, 2002, p. 293). Em síntese, a prova pode ser conceituada como um fato, instrumento ou meio hábil para se demonstrar sua existência. 
O Código de Processo Civil brasileiro, em seu art. 332, garante que "todos os meios legais, bem como os moralmente legítimos, ainda que não especificados neste Código, são hábeis para provar a veracidade dos fatos, em que se funda a ação ou a defesa”. Há, portanto, o permissivo legal de se demonstrar e existência de um fato pelos meios legais - aqueles previamente definidos (depoimento pessoal, confissão, documentos, testemunhas, perícia e inspeção judicial) - bem como por aqueles nos quais não existe disposição específica.

Nem todos os fatos são objeto da prova. Somente haverá necessidade de produzi-la quando há ocorrência de fatos controvertidos que tenham pertinência com o processo. Significa dizer que o processo não é campo para demonstração de fatos inconsequentes ou impertinentes. Assim, "o fato probando é sempre um fato singular ou determinado, relevante para a decisão de uma questão ou ao litígio cuja existência ou inexistência tenha necessária influência no pronunciamento judicial" (CINTRA, 2001, p. 7).

Sobre o objeto de prova, é pertinente, ainda, a lição de Ovídio Baptista da Silva (2002, p. 296-297), ao afirmar que:

Segundo princípio elementar de direito probatório, apenas os fatos devem ser objeto de prova, desde que a regra de direito se presume conhecida do Juiz. O próprio art. 332 do CPC, por nós referidos, confirma esta regra, ao dispor que a atividade probatória das partes dirige-se a estabelecer a veracidade dos fatos em que se funda a ação ou a defesa. A regra, porém, admite uma exceção, conforme dispõe o art. 337 do CPC: sempre que a parte alegar direito municipal, estadual, estrangeiro ou consuetudinário, cabe-lhe o ônus de provar tais regras de direito, a não ser qe o Juiz, por conhece-las, a dispense da prova. Da própria regra estabelecida no art. 332 do CPC pode-se extrair o seguinte corolário: hão de ser objeto de prova apenas os fatos em que se funda a ação ou a defesa, o que significa dizer que apenas os fato relevante para a decisão da controvérsia devem ser provados. 
De acordo, então, com o adágio latino iura novit curia, o direito não é objeto de prova, pois o juiz o conhece (salvo as excepcionalidades). Pode-se afirmar, ainda, que também independem de instrução probatória a circunstâncias expressas no art. 334 do Código de Processo Civil, quais sejam: (i) os fatos notórios; (ii) os afirmados por uma parte e confessados por outra; (iii) os admitidos como incontroversos; e (iv) os que em cujo favor milita presunção legal de existência e veracidade.

Levando em consideração que o juiz não pode deixar de decidir, aplicando o non liquet, é necessário que se definam critérios que permitam resolver a controvérsia quando não resulte provada a existência dos fatos essenciais ao caso concreto (MARINONI, ARENHART, 2004, p. 315). Há, então, o ônus que consiste em um "encargo, atribuído pela lei a cada uma das partes, de demonstrar a ocorrência dos fatos de seu próprio interesse para as decisões a serem proferidas no processo" (DINAMARCO, 2001, p. 50).

O ônus da prova, no direito brasileiro, é regido pelo disposto no art. 333 do Código de Processo Civil, incumbindo ao autor a demonstração de fato constitutivo do seu direito e, ao réu, a prova de fato impeditivo, modificativo ou extintivo do direito pleiteado. A pessoa responsável por uma determinada afirmação é também aquela que deve oferecer as provas necessárias para sustentá-la, sendo que pode haver convenção de maneira contrária, desde que não recaia sobre direito indisponível ou torne difícil o exercício de determinado direito.?

Portanto, o ônus da prova consiste na conduta processual exigida da parte para que a verdade dos fatos por ela afirmada seja admitida pelo juiz. Não há um dever de provar, mas um ônus, de modo que o litigante assume o risco de ter seu perder a demanda se não comprovar a existência dos fatos alegados.

7 Art. 333. O ônus da prova incumbe: I - ao autor, quanto ao fato constitutivo do seu direito; II - ao réu, quanto à existência de fato impeditivo, modificativo ou extintivo do direito do autor. Parágrafo único. É nula a convenção que distribui de maneira diversa o ônus da prova quando: I - recair sobre direito indisponível da parte; II tornar excessivamente difícil a uma parte o exercício do direito. 
Baseado então no ônus da prova, o magistrado pode formar sua convicção em torno dos fatos alegados, demonstrando que a prova, conforme dicção poética contida nas Ordenações Filipinas (Livro III, Título LXIII), é "o farol que deve guiar o juiz nas suas decisões".

\subsection{A Valoração da Prova no Ordenamento Jurídico Brasileiro}

Costuma-se dividir o procedimento probatório em três momentos fundamentais: (i) o momento de sua postulação, que é aquele em que a parte propõe a prova (em regra na petição inicial ou contestação); (ii) o deferimento, ou seja, o momento de sua admissão pelo juiz (em regra no saneamento do processo); e (iii) a produção, que, em regra, de acordo com o art. 336 do Código de Processo Civil, é realizada em audiência de instrução e julgamento, comportando situações excepcionais, como por exemplo, a juntada de documentos que devem, a princípio, serem trazidos à baila na fase postulatória, junto com a petição inicial ou contestação.

É de se destacar que em sendo o magistrado o destinatário da prova, caberá a ele, segundo o art. 130 do Código de Processo Civil, "de ofício ou a requerimento da parte, determinar as provas necessárias à instrução do processo, indeferindo as diligências inúteis ou meramente protelatórias". O que ocorre é uma mitigação do princípio dispositivo ${ }^{8}$, confirmando a busca pela verdade real defendida pelo processo moderno, em que as partes dividem com o magistrado a iniciativa de produzir a prova.

Ao encerrar a instrução probatória, de posse do arcabouço constante nos autos, o juiz formará seu convencimento. Assim, tomando conhecimento das alegações deduzidas pelas partes,

8 "Segundo este princípio, o juiz deve julgar a causa com base nos fatos alegados e provados pelas partes (iudex iudicare debet allegata et probata partium), sendoIhe vedada a busca de fatos não alegados e cuja prova não tenha sido postulada pelas partes" (BAPTISTA, 2001, P. 46). 
corroborada com a prova colhida no processo, o julgador definirá a quem deles corresponde o melhor interesse, segundo as regras de direito material e processual do ordenamento jurídico, e dará a composição do conflito trazido ao Poder Judiciário, fazendo prevalecer a pretensão que lhe seja correspondente.

Nessa perspectiva, é imperativa a necessidade de o raciocínio judicial corresponder a uma coerência lógica em relação ao conjunto das provas coligidas. Como regra geral o Código de Processo Civil, no art. 131, define que "o juiz apreciará livremente a prova, atendendo aos fatos e circunstâncias constantes dos autos, ainda que não alegados pelas partes; mas deverá indicar, na sentença, os motivos que lhe formaram o convencimento", o que consagra o princípio do livre convencimento motivado ou da persuasão racional.

Do escólio de Ovídio Baptista da Silva (2005, p. 332), colhe-se que o juiz tem:

[...] dever de fundamentar sua decisão, indicando os motivos e as circunstâncias que o levaram a admitir a veracidade dos fatos em que o mesmo baseara sua decisão. Cumpre-lhe indicar, na sentença, os elementos de prova com que formou sua convicção, de tal modo que a conclusão sentencial guarde coerência lógica com a prova constante dos autos.

A opção pelo sistema da persuasão racional também é evidenciada pela redação contida no art. 458 do Código de Processo Civil9, ao apresentar como requisito essencial da sentença os fundamentos, momento em que se analisam as questões de fato e de direito. Ademais, corrobora ainda com o referido dispositivo, o mandamento constitucional previsto no art. 93, IX, definindo a necessidade da fundamentação de todas as decisões proferidas pelo Poder Judiciário.

9 Art. 458. São requisitos essenciais da sentença: I - o relatório, que conterá os nomes das partes, a suma do pedido e da resposta do réu, bem como o registro das principais ocorrências havidas no andamento do processo;

II - os fundamentos, em que o juiz analisará as questões de fato e de direito; III - o dispositivo, em que o juiz resolverá as questões, que as partes lhe submeterem. 

colhe-se que:

Da lição de Humberto Theodoro Júnior (2005, p. 560),

Adotou o Código, como se vê, o sistema da persuasão racional, ou "livre convencimento motivado", pois: a) embora livre o convencimento, este não pode ser arbitrário, pois fica condicionado às alegações das partes e às provas dos autos; b) a observância de certos critérios legais sobre provas e sua validade não pode ser desprezada pelo juiz (arts. 335 e 366) nem as regras sobre presunções legais; c) o juiz fica adstrito às regras de experiência, quando faltam normas legais sobre as provas, isto é, os dados científicos e culturais do alcance do magistrado são úteis e não podem ser desprezados na decisão da lide; d) as sentenças devem ser sempre fundamentadas, o que impede julgamentos arbitrários ou divorciados da prova dos autos.

Assim, adotado pelo ordenamento jurídico brasileiro, o princípio da persuasão racional do juiz, tem por conteúdo a livre apreciação e avaliação da prova existente nos autos, podendo ser firmada a convicção de forma livre, desde que fundamentada. Trata-se de um meio termo entre o sistema da prova legal, em que a lei tarifa o valor da prova, e o princípio do livre convencimento, em que o julgamento depende da consciência do julgador, podendo até mesmo julgar contrário à prova (SLAIB FILHO, 2006, p. 184).

Ainda, sobre o princípio da persuasão racional, é de se mencionar a importância do disposto no art. 335 do Código de Processo Civil, dispondo que "em falta de normas jurídicas particulares, o juiz aplicará as regras de experiência comum subministradas pela observação do que ordinariamente acontece e ainda as regras da experiência técnica [...]". Deve, pois, verificar o juiz se existe uma norma jurídica sobre a prova produzida e, em caso afirmativo, aplicá-la. $\mathrm{Na}$ sua falta, entretanto, formulará seu juízo de acordo com o livre convencimento, mas observadas as regras de experiência.

Assim, os fatos trazidos pelas partes ao processo devem ser examinados pelo juiz e valorados em conformidade com os 
fundamentos científicos, bem como pelas experiências pessoais do julgador, analisando, sempre, os fatos da vida comum. Há uma intensa participação ativa do juiz no processo com o intuito de assegurar e efetividade da tutela jurisdicional, cabendo a ele o poder instrutório, que, de acordo como Luiz Guilherme Marinoni e Ségio Cruz Arenhart (2004, p. 59), consiste em:

[...] zelar por um "processo justo", capaz de permitir: I) a justa aplicação das normas de direito material; II) a adequada verificação dos fatos e a participação das partes em um contraditório real e não somente formal; e III) a efetividade da tutela dos direitos, com um maior zelo pela ordem no processo, com a repressão do litigante de má-fé, e com a determinação, a requerimento da parte, da tutela antecipatória, e da concessão, de ofício, da tutela cautelar.

Portanto, é através da atividade intelectual que busca a análise dos elementos probatórios resultantes da instrução processual que é possível a obtenção de conclusões sobre os fatos de interesse para o julgamento. É por meio da reconstituição histórica de fatos passados que se busca o entendimento de situações presentes. Para tanto, necessário valer-se dos resultados dos meios de prova aplicados, que lhe favorecem a captação dos informes emanados das fontes probatórias examinadas. (DINAMARCO, 2001, p. 81).

Corrediço é, portanto, que o exame da prova é uma delicada operação inerente ao exercício da jurisdição, devendo estar pautada na sensibilidade do magistrado. Entretanto, apesar da adoção do sistema da persuasão racional, existem, no ordenamento jurídico brasileiro, resquícios de prova tarifada que podem influenciar no livre convencimento do julgador.

\section{A PROVA TARIFADA E SUA APLICABILIDADE NO PROCESSO CIVIL}

Embora o sistema usual de valoração dos elementos da prova no processo civil brasileiro seja o do livre convencimento 
e não o da prova legal, o legislador persiste em estabelecer algumas diretrizes de caráter abstrato que limitam essa liberdade ao prefixar o valor probatório de determinados meios. Cumpre, pois, verificar a forma pela qual as supostas limitações se manifestam na seara processual e, por fim, analisar a postura do magistrado diante de tais circunstâncias.

\subsection{As Manifestações de Prova Tarifada no Ordenamento Jurídico Brasileiro}

Sobre o tema em comento, a obra da Cândido Rangel Dinamarco (2001, p. 78) é pródiga em relatar as diversas espécies de aparentes limitações ao princípio da persuasão racional do magistrado. Para o referido autor, os vínculos normativos à convicção do julgador estão presentes (i) em normas que estabelecem presunções legais relativas, (ii) em normas que limitam a admissibilidade ou eficácia de um meio probatório e (iii) em normas que afirmam ou disciplinam a eficácia anteriormente mencionada.

Em relação às presunções relativas, ao excluírem do objeto da prova o fato presumido, elas dispensam o juiz em analisar a veracidade das afirmações trazidas ao processo. Nesta regra pode ser abrangida a questão relativa à revelia, prevista no art. 319 do Código de Processo Civil ${ }^{10}$, que, segundo Ovídio Baptista da Silva (2002, p. 303), constitui a mais severa limitação em termos da matéria relativa ao principio da livre convicção em matéria probatória.

Entretanto, não existe uma higidez concreta acerca da referida norma. O juiz, como diretor do processo, não está adstrito a regra. Se o réu deixar de contestar a ação, ele não estará plenamente vinculado à presunção de veracidade dos fatos afirmados, podendo, inclusive, determinar a instrução probatória. Neste sentido é o escólio de João Batista Lopes (1999, p. 60), ao afirmar que "doutrina e jurisprudência não têm emprestado caráter inflexível a essa norma, podendo o juiz deixar de

10 Art. 319. Se o réu não contestar a ação, reputar-se-ão verdadeiros os fatos afirmados pelo autor. 
fazer incidir seu comando se o contrário resultar da análise do conjunto dos autos".

Ademais, conforme menciona Grahl Filho (2008, p. 62), a regra não é de natureza absoluta, dado que através de uma interpretação sistêmica do Código de Processo Civil, é possível observar que o próprio art. $320^{11}$ esvazia os efeitos da revelia em certos casos, quais sejam: (i) a contestação por parte de um autor quando do litisconsórcio passivo, (ii) a indisponibilidade dos direitos em litígio, e (iii) a falta do instrumento público que a lei considera necessário para a prova do ato afirmado na petição inicial.

Sobre as normas que limitam a admissibilidade ou eficácia de um meio probatório, por tal instituto, o legislador limita o poder de convencimento ou até mesmo a admissibilidade de certos meios de prova. Assim, configuradas sua ocorrência, o magistrado não poderá aceitar ou estará legalmente proibido de fundamentar sua convicção e seu julgamento exclusivamente com base no referido meio de prova.

Exemplificando o caso da inadmissibilidade do meio probatório, tem-se o art. 366 do Código de Processo Civil, verberando que "quando a lei exigir, como da substância do ato, o instrumento público, nenhuma outra prova, por mais especial que seja, pode suprir-lhe a falta”. Assim, os instrumentos públicos, quando obrigatórios para formação do ato jurídico, são indispensáveis para demonstração do fato que se pretende comprovar, não podendo substituí-los por outros meios probatórios.

Há de se observar, também, as limitações impostas à prova testemunhal, em momentos em que não se admite sua utilização quando só por documento ou por perícia puderem ser provados os fatos ${ }^{12}$, bem como naqueles em que é somente admitida de

11 Art. 320. A revelia não induz, contudo, o efeito mencionado no artigo antecedente:I - se, havendo pluralidade de réus, algum deles contestar a ação; II - se o litígio versar sobre direitos indisponíveis; III - se a petição inicial não estiver acompanhada do instrumento público, que a lei considere indispensável à prova do ato.

12 Art. 400. A prova testemunhal é sempre admissível, não dispondo a lei de modo diverso. O juiz indeferirá a inquirição de testemunhas sobre fatos: [...] II - que só por documento ou por exame pericial puderem ser provados. 
forma exclusiva nos contratos inferiores a dez salários mínimos na época da celebração ${ }^{13}$ ou, ainda, em casos em que houver começo de prova escrita ou não puder ser obtida da obrigação (casos específicos como parentesco, depósito necessário ou hospedagem em hotel) ${ }^{14}$.

Percebe-se, entretanto, que não há maiores divergências sobre a exigência da prova pericial em contraposição à prova testemunhal, dado que para o devido conhecimento de certos fatos, em sendo pressuposto a aptidão técnica e científica, não se pode admitir sua substituição (GRAHL FILHO, 2008, p. 66). O mesmo se diga em relação aos documentos, ou seja, "não se admite a prova testemunhal se o ato jurídico que se pretenda provar for daqueles para os quais se exija forma escrita, ou seja, quando a forma for da substância do ato" (WAMBIER, 2005, p. 454).

Além dos exemplos trazidos à baila, sobre a admissibilidade ou limitação de meios probatórios, é pertinente elencar demais hipóteses conforme bem retratado por Dinamarco (2001, p. 79):

[...] Também o art. 145 é uma regra legal sobre o valor das provas, ao exigir a perícia quanto aos fatos para cujo conhecimento seja indispensável um preparo técnico ou científico especializado; em relação a esses fatos afastam-se a prova testemunhal e mesmo o emprego das máximas de experiência do juiz (ais. 400, inc. II, e 335). Outra importantíssima limitação legal ao livre convencimento do juiz está nas disposições do art. 333 sobre a distribuição do ônus da prova, em razão das quais o juiz é obrigado a dar por inexistentes os fatos alegados e não provados (regra de julgamento). Em nível constitucional, o juiz é obrigado a negar qualquer eficácia às provas adquiridas por meios ilícitos.

13 Art. 401. A prova exclusivamente testemunhal só se admite nos contratos cujo valor não exceda o décuplo do maior salário mínimo vigente no país, ao tempo em que foram celebrados.

14 Art. 402. Qualquer que seja o valor do contrato, é admissível a prova testemunhal, quando: I - houver começo de prova por escrito, reputando-se tal o documento emanado da parte contra quem se pretende utilizar o documento como prova; II - o credor não pode ou não podia, moral ou materialmente, obter a prova escrita da obrigação, em casos como o de parentesco, depósito necessário ou hospedagem em hotel. 
Uma última classificação dos resquícios de prova tarifada no ordenamento jurídico são as normas que afirmam ou disciplinam a eficácia de determinados meios probatórios. Sobre elas tem-se que:

Da afirmação da eficácia da prova são exemplos os arts. 140 e 202 do Código Civil, que exigem a língua portuguesa para a validade dos documentos em juízo e a certidão do registro civil como prova do casamento; assim como os arts. 364, 365 e 378 do Código de Processo Civil, nos quais se indica a eficácia probatória dos documentos públicos, esclarece-se que as reproduções idôneas de documentos fazem a mesma prova que o original e afirma-se que os livros comerciais fazem prova contra seu autor etc. (DINAMARCO, 2001, p. 79).

Ao que se observa, os exemplos de prova legal desta espécie dizem respeito à prova documental. Tais regras determinam a amplitude de determinadas provas, desde que presentes os requisitos da legislação. Assim, na hipótese de sua ocorrência, quando apresentadas ao magistrado, deve haver uma vinculação de sua convicção, dado que trazem consigo a afirmação de veracidade de fatos específicos e previamente estabelecidos.

\subsection{A Postura do Magistrado Diante da Prova Tarifada}

Feita uma breve análise sobre as modalidades de circunstâncias pelas quais os resquícios de prova tarifada se manifestam no ordenamento jurídico brasileiro, bem como mencionados, de forma não exaustiva, exemplos expressos contidos no Código de Processo Civil, cumpre, por fim, analisar a influencia da prova legal no convencimento do magistrado. Em outros termos, para se alcançar o intento do presente ensaio, necessário verificar a conduta que deverá ser pautada pelo magistrado quando enfrentar situação semelhante.

Como visto, a prova constitui um instrumento pelo qual o julgador a utiliza para definir a verdade dos fatos que efetiva- 
mente originaram a lide. Ela (a prova), então, será apreciada, de acordo com a dicção contida no art. 131 do Código de Processo Civil, de forma livre, sempre se atentando aos fatos e circunstâncias contidos nos autos.

Entretanto, os ranços de prova legal contidos na legislação processual podem, teoricamente, afetar sua justa apreciação e conduzir a solução do litígio para situações não previstas pelas partes. Há uma possível colisão entre um sistema mais atual de valoração da prova - da persuasão racional - e outro princípio considerado antiquado pela doutrina moderna - prova tarifada. Resta, pois, questionar se há uma um convívio harmônico entre ambos os critérios de formação do convencimento ou uma limitação na livre convicção do magistrado.

Para Carlos Alberto Álvaro de Oliveira (s.d., s.n.), o índice de democratização do processo revela-se para um melhor norteamento em comparação com o antigo sistema da prova legal, dado que o pronunciamento sobre o fato passa a ser mais compreensível para o cidadão comum, que interage dialeticamente com a aproximação que deve ter a cidadania da função jurisdicional.

Assim, a forma de valoração da prova é crucial para a formação da convicção judicial e, em razão desta circunstância, precisa ser bem analisada para que resulte em uma prestação jurisdicional qualificada. $\bigcirc$ jurisdicionado, quando propõe uma demanda objetivando uma sentença condenatória, declaratória, constitutiva, mandamental ou executiva, pretende, antes mesmo da garantia de respeito a todos os princípios processuais lhe assegurados, uma solução justa ao conflito de interesses.

Por isso, segundo Dinamarco (2001, p. 73-74) existe, notoriamente, mas não expresso, uma graduação do poder de convicção segundo as fontes probatórias utilizadas. No entanto, esta "tarifação" não é ditada por lei, ou seja, não é uma observância obrigatória para o juiz e nem mesmo impõe-se para de modo regular em toso os casos. Esses critérios mencionados são de forma predominante subjetiva e correspondem a juízos ordinariamente feitos pelos próprios juízes e tribunais. 


\section{E prossegue o autor:}

Porque a experiência comum assim aconselha - e não porque assim mande a lei - o juiz dá mais crédito a um documento do que a uma testemunha; mais crédito à parte prestando depoimento pessoal onde reafirma os fatos afirmados pelo adversário (confissão), do que ao adversário quando os afirmou em seu próprio beneficio. Esses critérios, amadurecidos milenarmente, são culturais e subjetivos e nem sempre prevalecem, podendo em tese ser tão grande o poder de convicção de uma testemunha, que chegue ao ponto de superar a versão contida em documento trazido aos autos; e podendo até haver elementos que, em dado processo, levem o juiz a formar convencimento em sentido contrário ao da confissão prestada por uma das partes. Já se foi o tempo em que à confissão se atribuía a majestade de rainha das provas. Essa soberana caiu do trono e hoje os conhecimentos científicos do direito já permitem perceber que ela sequer é meio de prova.

Certo é que a convicção formada pelo magistrado está livre de formalidades. Ele é livre na apreciação dos elementos de prova, devendo sobpesá-los e submetê-los aos rigores do seu raciocínio, razão pela qual a formação de sua convicção, desde que demonstrado seu convencimento, não está sujeita a regras que lhes atribuam valor qualitativo.

Entretanto, conforme preleciona Carlos Alberto Álvaro de Oliveira (s. d., s. n.):

O problema é que permanecem às vezes no espírito dos juízes, nomeadamente em fatores de ordem cultural, resquícios da prova tarifada, como se a confissão, a perícia ou documentos houvessem de prevalecer sempre sobre os demais tipos de prova. Todavia, bem entendido o sistema da persuasão racional, não se pode conceber regra de natureza probatória a priori nem de caráter geral: tudo há de depender do exame in concreto do caso e no contexto dos elementos constantes dos autos, material sobre o qual haverá o órgão 
judicial de exercer o maior cuidado o seu exame crítico e extrair a verdade provável e possível.

Assim, o sistema do livre convencimento, que talvez represente o mais importante entre todos os pilares do direito probatório, tem como premissa a necessidade de julgar segundo as imposições da justiça para cada caso, dado que é flagrante a inaptidão do legislador em prever tão minuciosamente todas as situações possíveis em relação à prova. Ademais, não é factível a tarefa de editar tabelas tarifárias indicando o valor probatório de cada fonte em cada situação imaginável. Seria, aliás, uma ingênua fantasia e ao mesmo tempo um absurdo (DINAMARCO, 2001, p. 74).

Mostra-se imprescindível, portanto, que a utilização da persuasão racional não redunde em puro arbítrio em relação à decisão judicial. $O$ julgador, no momento da prestação jurisdicional, precisa se ater à racionalidade lógica e agir em conformidade com a experiência que o guia. O próprio art. 335 do Código de Processo Civil, anteriormente mencionado, orienta o magistrado para aplicação das regras de experiência comum, que, indubitavelmente, devem ser utilizadas no campo de apreciação das provas.

Daí porque se pode chegar a conclusão que:

[...] a presença de resquícios de prova tarifada no Código de Processo Civil "não se trata de ressuscitar o sistema da prova legal nem prolongar-lhe a vida como predicado do processo civil da atualidade, mas simplesmente de inserir alguns poucos critérios racionais ditados pela experiência comum do legislador. São pequenas ilhas de prova legal que não infirmam o sistema adotado (DINAMARCO, 2001, p. 78).

Aparentemente, os fragmentos de prova legal podem, então, conviver pacificamente com o sistema adotado pela legislação brasileira, evitando o arbítrio do julgador em determinados casos. Tudo depende de uma interpretação sistêmica em relação a outros dispositivos, mormente através do art. 131 do Código de Processo Civil, que trata da livre apreciação da prova 
com a indicação dos motivos que resultaram na formação da convicção adotada.

É certo que mesmo havendo todas essas ponderações sobre a harmonia entre os sistemas, é possível que em algum momento exista uma anomalia em relação à apreciação da prova. É neste instante em que postura do julgador será essencial para satisfazer o conflito de interesses. $\mathrm{O}$ magistrado, como agente qualificado que é, deverá ponderar sobre a credibilidade do meio probatório que pretende valorar de forma positiva para a formação de seu convencimento e, caso necessário, infirmar de modo motivado as regras mais formais de valoração.

Surge, então, a necessidade de uma excelente motivação da decisão, porque ela "expõe o raciocínio judicial à validação social. É a partir da motivação que se pode avaliar em termos extrajurídicos se a sociedade concorda com o conteúdo axiológico da decisão" (DIAS, 2002, s. n.). É, então, através da exteriorização da formação do convencimento, que se dá pela motivação, que serão avaliados todos os seus aspectos, inclusive em relação à valoração da prova, podendo os jurisdicionados afiançarem confiança ou irresignarem-se pelos meios cabíveis.

\section{CONSIDERAÇÕES FINAIS}

$\mathrm{Na}$ qualidade de ser político, o homem, desde o momento em que passou a viver em sociedade, necessita que alguém dite a solução dos conflitos que possa haver entre os indivíduos. Assim, a presença do fenômeno denominado jurisdição e o aparecimento da figura do juiz asseguram àqueles que tenham uma pretensão resistida a busca por uma solução mais justa em relação ao problema, evitando-se a autotutela. É perceptível, então, a evolução dos sistemas jurídicos em relação às decisões, principalmente quando a avaliação da prova.

Em uma linha de evolução, que parte do sistema de avaliação da prova de uma forma praticamente tarifada, passando por um momento de livre convencimento absoluto, 
para, por fim, alcançar o sistema da persuasão racional, observase que a tendência de o magistrado em ficar mais liberado de uma cadeia formal de apreciação da prova.

No decorrer da atividade de apreciação probatória pode, entretanto, ocorrerem situações em que os resquícios do obsoleto sistema da prova legal dificultem ou vinculem a atividade do magistrado. Há que se ter em mente, no entanto, que certas imposições de prova tarifada podem, em um primeiro momento, evitar a arbitrariedades cometidas pelo julgador e, consequentemente, possibilitar a convivência harmônica entre os sistemas.

Ocorre que, mesmo de forma harmônica, pode haver uma anomalia que conduza o juiz a ponderar sobre as circunstâncias do caso. Sua tarefa, então, não pode ficar enraizada numa concepção mecânica da função jurisdicional, devendo encarar a ordem processual vigente de uma forma sistêmica e, caso necessário, formar sua convicção infirmando dispositivos que conduzem à tarifação da prova, atento sempre na necessidade de motivar sua decisão, mormente nestes casos, dado que sua convicção será examinada pela sociedade.

Portanto, é de concluir-se que não é característico da função jurisdicional, em razão da credibilidade que se precisa dada à figura do magistrado, a supressão de todos os meandros captados no decorrer da relação processual e no momento da valoração da prova.

\begin{abstract}
Intends to analyze the remains of appraised proof in Brazilian civil proceedings and the influence on free conviction of the judge. Looks back on the figure of the judge, the judgments and the conviction systems. Brings up notes on the general theory of proof and manner of their valuation. List the means by which the appraised proof is manifested in Brazilian civil procedure, and then defines the position of judge before such evidence as opposed to the principle of free conviction motivated.
\end{abstract}

Keywords: Appraised proof. Valuation of proof. Judge's conviction. 


\section{REFERÊNCIAS}

ARISTÓTELES. Ética a Nicômaco. Traduçlo de Pietro Nassetti. SØo Paulo: Martin Claret, 2001.

BARBI, Celso Agrícola. Comentários ao Código de Processo Civil: Lei n ${ }^{\circ}$ 5.869, de 11 de janeiro de 1973. 6. ed. Rio de Janeiro: Forense, 1991, v. 1.

BIGAL, Valmir. A obrigatoriedade das decisões judiciais. Disponível em <http://www.abdir.com.br/doutrina/ver.asp?art_id=\&categoria= Direito Civil Constitucional > Acesso em: 2 jun. 2010.

BRASIL. Constituiçొo (1988). Constituiç̣o da República Federativa do Brasil. Disponível em: 〈http://www.planalto.gov.br〉. Acesso em: 2 jun. 2010.

. Supremo Tribunal Federal. AgR em AI 162089/DF, Segunda Turma, rel. Min. Carlos Velloso, j. em 12 dez. 1995, DJU de 15 mar. 1996, p. 7.209. Disponível em <http://www.stf.jus.br>. Acesso em: 2 jun. 2010.

$=$ Lei 5.869, de 11 de janeiro de 1973. Código de processo civil. Disponível em: <http://www.planalto.gov.br>. Acesso em: 2 jun. 2010.

CARNELUTTI, Francesco. A prova civil. Tradução de Lisa Pary Scarpa. Campinas: Bookseller, 2001.

CINTRA, Antônio Carlos de Araújo. Comentários ao Código de Processo Civil. Rio de Janeiro: Forense, 2001.

DIAS, Jean Carlos. O problema dos limites da prova e sua valoraçlo no moderno estudo do Processo Civil. Jus Navigandi: Teresina, ano 7, n. 60, nov. 2002. Disponível em: <http://jus2.uol.com.br/doutrina/texto. asp?id=3418>. Acesso em: 2 jun. 2010.

DINAMARCO, Cândido Rangel. Fundamentos do Processo Civil Moderno. 5 ed. São Paulo: Malheiros, 2002, v. 1.

DINAMARCO, Cândido Rangel. Instituições de direito processual civil. S\o Paulo: Malheiros, 2001, v. 3.

GRAHL FILHO, Renato Hartwig. As limitações impostas ao princípio da persuasão racional pela prova tarifada. 2008. Trabalho de Conclusão de Curso. (Graduação em Direito) - Universidade Federal de Santa Catarina. Orientador: Francisco José Rodrigues de Olvieira Filho. 
GRECO. Leonardo. Prova no processo Civil: do Código de 1973 ao novo Código Civil. In: COSTA, Hélio Rubens Batista Ribeiro; RIBEIRO, José Horácio Halfeld Rezende; DINAMARCO, Pedro da Silva. (coords.). Linhas mestras do processo civil. São Paulo: Atlas, 2004.

GRINOVER, Ada Pellegrini. A inafastabilidade do controle jurisdicional e uma nova modalidade de autotutela: parágrafos únicos dos artigos 249 e 251 do código civil. Revista brasileira de direito constitucional, São Paulo, v. 5, n. 10, p. 13-19, jul./dez. 2007. Disponível em: 〈http://bdjur.stj.jus.br/ dspace/handle/2011/26126>. Acesso em: 2 jun. 2009.

GUIMARIES, Mário. O juiz e a funç】o jurisdicional. Rio de Janeiro: Forense, 1958.

LOPES, João Batista. A Prova no Direito Processual Civil. São Paulo: Revista dos Tribunais, 1999.

MARINONI, Luiz Guilherme; ARENHART, Sérgio Cruz. Manual do processo de conhecimento. 3. ed. São Paulo: Revista dos Tribunais, 2004.

MARQUES, José Frederico. Instituições de direito processual civil. Rio de Janeiro: Forense, 1958.

OLIVEIRA, Carlos Alberto Álvaro de. Problemas atuais da livre apreciaç】o da prova. Porto Alegre: UFPR, s.d. Acesso em: <http://www6. ufrgs.br/ppgd/doutrina/oliveir3.htm>. Acesso em: 2 jun. 2010.

PORTUGAL. Ordenações Filipinas. Coimbra: Instituto de História e Teoria das Idéias da Universidade de Coimbra, 1998. Disponível em: <http://www.uc.pt/ihti/proj/filipinas〉. Acesso em 2 jun. 2010.

SILVA, Ovídio A. Baptista da; GOMES, Fábio. Teoria geral do processo civil. 3. ed. rev. e atual. SØo Paulo: Revista dos Tribunais, 2002.

SLAIBI FILHO, Nagib. Sentença cível: fundamentos e técnica. 6. ed. Rio de Janeiro: Forense, 2006.

THEODORO JUNIOR, Humberto. Curso de direito processual civil: teoria geral do direito processual civil e processo de conhecimento. 43. ed. Rio de Janeiro: Forense, 2005.

WAMBIER, Luiz Rodrigues; ALMEIDA, Flávio Renato Correia de; TALAMINI, Eduardo. Curso avançado de processo civil. 7. ed. São Paulo: Revista dos Tribunais, 2005. 